\title{
THEORY AND HISTORY OF LAW AND STATE
}

DOI https://doi.org/10.30525/978-9934-26-045-2-1

\section{СВІТОВІ ТЕНДЕНЦІЇ ЩОДО ЗАПРОВАДЖЕННЯ КОНЦЕПЦЇ̈ ДЕРЖАВНО-ГРОМАДЯНСЬКОГО ПАРТНЕРСТВА В СФЕРУ СТОМАТОЛОГІї}

\author{
Богату C. I. \\ кандидат медичних наук, магістр державного управління, \\ асистент кафедри фармакології та фармакогнозіі \\ Одеського національного медичного університету, \\ лікар-стоматолог \\ м. Одеса, Україна
}

Стоматологічне здоров'я - важливий компонент загальносоматичного здоров'я та благополуччя населення загалом та індивіда зокрема. Незважаючи на те, що більшість захворювань порожнини рота можна попередити, поширеність карієсу та запальних захворювань пародонта все одно є дуже високою та досягає позначки в 90-95\% залежно від регіону, статі, віку. При цьому як захворювання зубів, так i захворювання пародонта призводять до порушень не лише зубощелепної системи, а і травної, дихальної, порушення дикції, естетики, призводять до проблемами із комунікацією в соціумі і як наслідок розвитку психологічних проблем, виходячи таким чином за межі суто медичної площини у соціально-економічну. 3 іншого боку, вартість стоматологічних послуг є досить високою, що значно обмежує доступ громадян до якісного стоматологічного обслуговування. Як наслідок, ми спостерігаємо невтішну тенденцію до зростання стоматологічної захворюваності, особливо серед осіб активного працездатного віку. Захворювання порожнини рота представляють собою серйозний тягар для здоров'я в багатьох країнах світу і впливають на людей протягом усього їхнього життя, викликаючи біль, дискомфорт, потворність і навіть смерть. Ці хвороби мають загальні фактори ризику розвитку аутоімунних захворювань таких як гломерулонефрит, ендокардит, ревматоїдний артрит тощо [8].

Лікування захворювань порожнини рота є дорогим і зазвичай не входить в систему загального медичного страхування. У більшості 
країн 3 високим рівнем доходів стоматологічне лікування становить в середньому 5\% загальних витрат на охорону здоров'я і $20 \%$ особистих витрат на охорону здоров'я [8]. Значний вплив стоматологічної патології відчувається на малозабезпечені прошарки населення як у країнах, що розвиваються, так і в розвинених країнах. Ризик захворювань порожнини рота залежить від умов та способу життя, факторів навколишнього середовища, а також наявності і доступності послуг 3 гігієни порожнини рота. Доступність профілактичних програм гігієни порожнини рота різна у різних країнах світу [6].

Незважаючи на значний прогрес, який спостерігається у стоматологічній галузі із застосування найновітніших матеріалів, інструментів, технологій, у світі і досі є країни або окремі регіони, в яких немає постійного доступу до стоматологічної допомоги, в яких люди не обізнані з питань догляду за ротовою порожниною та профілактики стоматологічних захворювань, не усвідомлюють всю важливість профілактичних заходів та не мають доступу до якісної кваліфікованої стоматологічної допомоги.

Переважна більшість країн з низьким і середнім рівнем доходів не можуть забезпечити населення своїх країн якісною стоматологічною допомогою (профілактика та лікування) за рахунок державних коштів [8] через велику вартість та ресурсозатратність даної галузі [4]. Можливості державного фінансування стоматологічної галузі не відповідають сучасному матеріально-технічному стану стоматології, оскільки прогрес в обладнанні, матеріалах, технологіях значно випереджає можливості бюджетного фінансування повному обсязі у різних державах світу, що є очевидним. Навіть в розвинутих країнах з високим рівнем ВВП сфера охорони здоров'я (ОЗ) загалом та стоматологія зокрема не $\epsilon$ повністю державною, а складається із трьох компонентів приватного, суспільного та страхового [3].

Все вище перераховане робить актуальним проблему трансформації та реформування стоматологічної галузі, зміну форми та організаційної структури, форми господарювання закладів О3, що надають стоматологічну допомогу. Держава не може передбачити та не здатна забезпечити тисячі громадських потреб та послуг. Саме тому в цивілізованих країнах світу з високим рівнем життя населення, держава зберігає за собою мінімум впливу на суспільні процеси, в тому числі в охороні здоров'я, решта віддається громадськості і таким чином, 3 одного боку, реалізується право громадян на участь у здійсненні публічної політики в сфері О3, з іншого боку, громадськість, організації 
громадянського суспільства, соціально активні та свідомі громадяни, які $\epsilon$ членами громадянського суспільства, забезпечують соціальну функцію держави, яку вона не може виконати в повному обсязі, таким чином забезпечуючи надання медичної та стоматологічної допомоги соціально незахищеним прошарки населення. Важко переоцінити важливість налагодження співпраці між державою і громадянським суспільством у всіх сферах, в тому числі й у сфері О3.

Отже, перспективним та ефективним напрямком забезпечення змін у стоматології є залучення до співпраці із державними органами в галузі стоматології громадських організацій як рушійної сили, як представника суспільства, професіоналів у даному питанні та приватного сектору, який зможе забезпечити матеріальну базу майбутніх перетворень. Така взаємодія отримала назву державно-громадянського партнерства (ДГП), яке є вигідним для всіх учасників взаємодії.

Як свідчить зарубіжний досвід, О3 $є$ тою сферою, де ДГП знайшло достатньо широке розповсюдження, причому як в розвинутих країнах, так і в тих, що розвиваються. В галузі О3 ДГП може бути реалізовано у наступних формах: волонтерство; тристороннє партнерство «держава - громадські (неурядові організації) - приватний сектор (бізнес)»; соціальне підприємництво (СП) [1].

Проте протягом останніх декількох десятирічь, межі між трьома секторами - державним, приватним та громадським - стають все більш розмитими, причиною чого вважать те, що достатньо велика кількість новаторських організацій, які представляють різні сектори, почала використовувати бізнес підходи для досягнення соціальних цілей, тобто одна форма державно-громадянського партнерства може легко переформатовуватися в іншу.У всьому світі цей тренд проявляється різними формами - корпоративна соціальна відповідальність, венчурна філантропія, імпакт інвестування, СП тощо. По мірі визрівання цього тренду, він все більше стає відомим як «четвертий сектор» економіки [10]. За даними Chavan S. at al. (2012) [5] заохочення ДГП може грати ключову роль, оскільки кожен сектор робить значний внесок в покращення стану порожнини рота. Одне 3 головних переваг заохочення такого партнерства Chavan S. at al. вбачають в тому, що, коли державний і приватний сектори об'єднуються, вони долають слабкості один одного і працюють як потужна машина, щоб вирішити стоматологічні проблеми із максимальною користю для населення [5]. Аналогічної думки дотримуються і Somaraj V. et al. (2015) [9], які також наголошують на необхідності приділити значну увагу навчанню 
догляду за зубами дітей та учнів, оскільки від їх навчання правильній гігієні порожнині рота в майбутньому залежатиме здоров'я нації.

Vikram P.A.et al. (2018) [11], наводячи успішні приклади ДГП, які вже здійснили в Iндї, наголошують на необхідності продовжувати таку взаємодію. Такі партнерські відносини поєднують політичні, економічні та соціальні сили для підвищення обізнаності про стоматологічні потреби населення, сприяють поширенню знань про порожнину рота, захворювання цієї ділянки та їх профілактику. Їх спільні зусилля виробляють такий суспільний резонанс, що значно перевищує результати їх окремої діяльності. Необхідно заохочувати ДГП з профілактики, лікування та просування послуг з оздоровлення порожнини рота [11]. На думку Mosha H.J. (2008) [7] самотужки державна система ОЗ не зможе справитися із ситуацією, що склалася щодо захворювань порожнини рота - різке зростання захворювань ротової порожнини через низький рівень життя та умови навколишнього середовища, що постійно змінюються. Покращити стан орального здоров'я населення країн, що розвиваються, можливо лише за рахунок взаємодії держави, громадських організацій та приватного сектору. Таке партнерство, окрім покращення стану стоматологічного здоров'я населення, поглиблення знань щодо гігієни ротової порожнини та стоматологічної профілактики, також сприятиме зміцненню національної системи О3, функціональній інтеграції та стійкому функціонуванню плюралістичної системи ОЗ. Успішні приклади взаємодії держави та громадських організацій за підтримки бізнес-структур сприятимуть залученню нових партнерів до взаємодії у майбутньому.

Дещо складніша ситуація із можливістю впровадження ДГП склалася в Україні. Так, згідно із аналітичним звітом [2], сьогодні в Україні представники професійної громадськості не мають достатніх важелів впливу на формування державної політики, а потенціал взаємодії «держава-громадянське суспільство» використовується не в повній мірі. Особливо гостро постає дана проблема на фоні масового незадоволення населення України якістю медичного обслуговування, яке вони одержують. У аналітичному звіті [2] представлені результати опитування, проведеного Інститутом Горшеніна, яке показало, що 80\% українців незадоволені якістю медичної допомоги. До інших актуальних проблем охорони здоров`я дослідники відносять низьку якість медичних послуг (18,2\%), низьку зарплату фахівців (16,2\%), байдужість лікарів $(15,1 \%)$, хабарі $(12,8 \%)$, поганий стан лікарень $(10,8 \%)$, велику завантаженість лікарів $(6,2 \%)$. Моніторинг громадськості викликає більш, ніж просто стурбованість. За даними звіту 
основними напрямками, в яких на даному етапі відбувається співпраця «держави - громадянське суспільство», є нормопроєктування; правопросвітництво; ДГП; контроль якості медичної допомоги [2].

ДГП в охороні здоров'я може реалізовуватися значно ширше і всі передумови для цього в Україні $є$.

\section{Література:}

1. Богату C.I. Добровольчий підхід в стоматології як форма реалізації державно-громадянського партнерства / C.I. Богату // Державне управління: удосконалення та розвиток. - 2021. - № 1. URL: http://www.dy.nayka.com.ua/?op=1\&z=1943. DOI: 10.32702/23072156-2021.1.33

2. Квартальний звіт Аналітико-експертного центру досліджень у сфері громадського здоров'я при ВГО «Фундація медичного права та біоетики України» «Участь громадськості у сфері охорони здоров’я» [Електронний ресурс]. - Режим доступу: http://medicallaw.org.ua/ fileadmin/user_upload/pdf/Zvit_II_kvartal.pdf.

3. Павленко О.В. Медична стоматологічна допомога в моделях медичного страхування різних країн / О.В. Павленко, О.М. Вахненко, Л.Г. Срмакова [та ін.] // Сучасна стоматологія. - 2019. - №5. С. $100-103$.

4. Чопчик В. Державно-приватне партнерство -модель для реформування університетської клініки / В.Чопчик // Ukrainian scientific medical youth journal. - 2019. - №4 (112).- C. 47-53.

5. Chavan S. Public-private partnership to enhance oral health in India. / S.Chavan, U.Kemparaj, O.N.Baghele, A.Rajdha // J Interdiscip Dentistry [serial online] 2012 [cited 2020 Oct 23];2:135-7. - Available from: https://www.jidonline.com/text.asp?2012/2/2/135/100609

6. Dugdill L. Evaluation of international case studies within «Live. Learn. Laugh»: a unique global public-private partnership to promote oral health / L. Dugdill, C.M.Pine // Internatiomal Dental Journal. - 2011. Vol.61. - Issue s2. - P.22-29.. - doi: 10.1111/j.1875-595X.2011.00035.x. PMID: 21770937.

7. Mosha H.J. Increasing Quality and Access to Oral Health Care through Public-Private Partnerships / H.J.Mosha // Tanzania Dental Journal. - 2008. - Vol. 15. - No. 1. - P. 25-29. - Avalaible from: https://www.ajol.info/index.php/tdj/article/view/48375

8. Oral Health [Electronic resource]. - Avalaible from: https://www.who.int/news-room/fact-sheets/detail/oralhealth?utm_source=volunteerforever.com\&utm_medium=referral\&utm_cam 
paign=dental-volunteer-abroad-medical-mission-trips-dentists-students https://onlinelibrary.wiley.com/doi/full/10.1111/j.1875-595X.2011.00035.x

9. Somaraj V. Smiles for Life: Model for Child Oral Health Promotion A Proposal / V.Somaraj, R.P.Shenoy, G.S.Panchmal, P.Jodalli, L.Sonde //Int J Oral Health Med Res. - 2015. - Vol. 2(3). - 85-87.

10. Ukrainian Social Academy [Електронний ресурс]. - Режим доступу: https://social-academy.com.ua/

11. Vikram P.A. Public Private Partnership'- Public Private Partnership: The New Panacea in Oral Health / P.A.Vikram // Advances in Dentistry \& Oral Health. - 2018. - №8 (2). - P. 39-42. DOI: 10.19080/ADOH.2018.08.555734. - $\quad$ Avalaible from: https://juniperpublishers.com/adoh/pdf/ADOH.MS.ID.555734.pdf

DOI https://doi.org/10.30525/978-9934-26-045-2-2

\title{
ДЕРЖАВНА ПІДТРИМКА РОЗВИТКУ ГРОМАДЯНСЬКОГО СУСПІЛЬСТВА: УМОВИ, ФАКТОРИ, НАПРЯМИ
}

\author{
Волинець С. C. \\ начальник управління організаційної роботи апарату \\ Дніпропетровської обласної державної адміністрації \\ м. Дніпро, Украӥна
}

Становлення та розвиток громадянського суспільства неможливі без сприяння з боку держави та цілеспрямованої державної підтримки. Остання, у свою чергу, потребує розуміння умов та факторів, що впливають на цей процес.

Так, до ключових суспільних явищ та процесів, необхідних для розвитку громадянського суспільства, слід, насамперед, віднести:

I. Бажання влади та політичної еліти сприяти розвитку громадянського суспільства, а також їх готовність до співпраці з громадськістю. Для влади це нелегкий вибір, адже він, з одного боку, дозволяє ій використовувати потенціал громадськості, поклавши на неї виконання завдань державного, регіонального і місцевого розвитку, а 3 іншого - створює певні обмеження, робить іiі підзвітною та підконтрольною громадськості, позбавляе самостійності в ухваленні рішень. Підтримка розвитку громадянського суспільства грунтується на 